\title{
REAKSI PASAR ATAS SAHAM YANG MASUK DAN KELUAR INDEKS LQ 45
}

\author{
Sari Indrawati \\ sariindrawati40@gmail.com
}

Universitas Airlangga

\begin{abstract}
ABSTRAK
Penelitian ini bertujuan untuk menguji reaksi pasar saham ketika saham ditambahkan dan dihapus dari indeks LQ 45. Reaksi pasar diuji dengan menggunakan metode event study untuk mengetahui apakah terdapat rata-rata abnormal return yang signifikan, rata-rata cumulative abnormal return dan ratarata. rasio volume di sekitar tanggal pengumuman. Penelitian ini juga menguji apakah terdapat perbedaan yang signifikan pada rata-rata abnormal return, ratarata cumulative abnormal return dan rasio volume rata-rata saham yang ditambahkan dan dihapus dari indeks LQ 45 dengan menggunakan uji-t sampel independen. Hasil penelitian menunjukkan terdapat reaksi pasar yang positif ketika saham ditambahkan ke indeks LQ 45 sedangkan saham yang dihapus dari indeks LQ 45 menunjukkan reaksi pasar yang negatif. Independent-sample ttest menunjukkan ada perbedaan yang signifikan rata-rata abnormal return antara saham yang ditambahkan dan dihapus dari indeks LQ 45 dan tidak ada perbedaan yang signifikan pada rata-rata abnormal return kumulatif dan rasio volume rata-rata antara saham yang ditambahkan dan dihapus dari indeks LQ 45.

Kata Kunci: Indeks LQ 45, Event Study, pengembalian abnormal rata-rata, pengembalian abnormal rata-rata kumulatif, rasio volume rata-rata.
\end{abstract}

\section{ABSTRACT}

This study aims to test the reaction of the stock market when stocks are added to and deleted from index $L Q 45$. The market reaction is tested using the event study method to determine whether there is a significant average abnormal return, cumulative average abnormal return and average volume ratio around the announcement date. This study also examines whether there is a significant difference in average abnormal return, cumulative average abnormal return and average volume ratio of the stocks added to and deleted from index $L Q 45$ using independent-samples $t$-test. The result shows there is a positive market reaction when stocks are added to index LQ 45 while stocks deleted from index LQ 45 shows negative market reaction. Independent-samples t-test shows there is significant difference in average abnormal return between stocks added to and deleted from index $L Q 45$ and there is no significant difference in average cumulative abnormal returns and average volume ratio between stocks added to and deleted from index $L Q 45$.

Keywords: Index LQ 45, event study, average abnormal return, cumulative average abnormal return, average volume ratio. 


\section{PENDAHULUAN \\ Latar Belakang}

Pasar modal di Indonesia memegang dua fungsi penting, yaitu sarana pendanaan jangka panjang bagi perusahaan untuk mendapatkan dana dari investor dan sarana kegiatan berinvestasi pada instrumen pasar modal bagi masyarakat untuk mendapatkan keuntungan. Salah satu pedoman yang digunakan investor dalam berinvestasi di pasar modal adalah indeks harga saham. Indeks harga saham dapat menunjukkan kinerja pasar modal sebagai indikator yang menggambarkan pergerakan harga saham (Darmadji dan Fakhruddin, 2001:95). Salah satu indeks harga saham yang digunakan di pasar modal Indonesia adalah Indeks Harga Saham Gabungan (IHSG). IHSG merupakan indikator kinerja Bursa Efek Indonesia (BEI) secara umum dengan memasukkan semua saham perusahaan tercatat di BEI yang digunakan sebagai komponen perhitungan Indeks.

Bursa Efek Indonesia memiliki beberapa indeks saham selain IHSG, seperti Indeks Sektoral, Jakarta Islamic Index dan Indeks LQ 45. Indeks LQ 45 terdiri dari 45 saham emiten yang dipilih berdasarkan pertimbangan likuiditas dan kapitalisasi pasar, dengan kriteria-kriteria yang sudah ditentukan. Tujuan indeks LQ 45 adalah sebagai pelengkap IHSG dan khususnya untuk menyediakan sarana yang obyektif dan terpercaya bagi analisis keuangan, manajer investasi, investor dan pemerhati pasar modal lainnya dalam memonitor pergerakan harga dari saham-saham yang aktif diperdagangkan. Indeks LQ 45 menunjukkan nilai kapitalisasi pasar dari 45 saham terlikuid atau yang biasa disebut dengan saham blue-chip. Nilai kapitalisasi pasar indeks LQ 45 mencakup 60,2\% pasar modal Indonesia (www.idx.co.id). Bursa Efek Indonesia secara rutin memantau perkembangan kinerja saham perusahaan yang masuk dalam perhitungan indeks LQ 45. Indeks LQ 45 disesuaikan setiap enam bulan, yaitu setiap awal bulan Februari dan Agustus. Perusahaan yang dinilai tidak memenuhi kriteria akan dikeluarkan dari indeks, sehingga komposisi saham yang terdapat dalam indeks tersebut akan selalu berubah.

Informasi dibutuhkan oleh investor untuk menentukan keputusan jual beli. Informasi dapat berasal dari dalam perusahaan maupun dari luar perusahaan. Salah satu informasi yang berasal dari luar perusahaan dan dapat mempengaruhi harga saham adalah pengumuman yang berhubungan dengan likuiditas. Informasi yang berhubungan dengan likuiditas misalnya saham yang masuk atau keluar indeks LQ 45. Investor menyukai saham yang likuid untuk mendapatkan keuntungan berupa capital gain.

Perubahan komposisi indeks telah menarik banyak perhatian akademisi untuk 
meneliti reaksi pasar atas saham yang masuk dan keluar dari suatu indeks di sekitar tanggal pengumuman berkaitan dengan informasi yang terkandung dalam pengumuman tersebut. Namun, penelitian terdahulu mendokumentasikan hasil yang beragam. Liu (2000) dan Duque dan Madeira (2005) Menemukan bahwa terdapat abnormal return positif signifikan atas saham yang masuk indeks dan abnormal return negatif signifikan atas saham yang keluar dari suatu indeks. Sementara volume perdagangan bereaksi positif. Namun Bildik dan Gülay (2008) menemukan bahwa volume perdagangan bereaksi negatif. Sementara Qiu dan Pinfold (2008) tidak menemukan reaksi harga dan volume atas saham yang masuk maupun keluar indeks.

Hasil dari penelitian sebelumnya mendorong peneliti untuk menguji reaksi pasar atas saham yang masuk dan keluar dari indeks LQ 45. Reaksi pasar diuji dengan metode event study sehingga dapat diketahui reaksi harga yang ditunjukkan dengan average abnormal return, cumulative average abnormal return dan reaksi volume perdagangan yang ditunjukkan dengan average volume ratio. Reaksi pasar yang diukur menggunakan average abnormal return menggambarkan reaksi harian rata-rata abnormal return seluruh sampel atas saham yang masuk dan keluar indeks LQ 45. Cumulative average abnormal return menggambarkan akumulasi harian AAR dari hari ke hari untuk melihat abnormal return yang didapat investor di sepanjang periode uji. Sedangkan average volume ratio menggambarkan aktivitas perdagangan abnormal. Selain itu, perlu diuji perbedaan reaksi harga dan volume saham atas saham yang masuk dengan saham yang keluar dari indeks LQ 45. Indeks LQ 45 memiliki karakteristik yang berbeda dengan indeks negara-negara lain dalam hal regulasi indeks, sehingga perlu mengkaji informasi yang berkaitan dengan hal ini memberikan informasi berarti atau tidak bagi pelaku pasar modal di Indonesia

\section{Rumusan Masalah}

“Apakah terdapat reaksi pasar yang ditunjukkan dengan reaksi harga dan volume saham atas saham yang masuk dan keluar dari indeks LQ 45 serta ppakah terdapat perbedaan reaksi harga dan volume saham atas saham yang masuk dan keluar dari indeks LQ 45 ?"

\section{Tujuan Penelitian}

Penelitian ini bertujuan untuk mengetahui reaksi pasar yang ditunjukkan dengan reaksi harga dan volume saham atas saham yang masuk dan keluar dari indeks LQ 45 serta mengetahui perbedaan reaksi harga dan volume saham atas saham yang masuk dan 
keluar dari indeks LQ 45.

\section{LANDASAN TEORI DAN PENGEMBANGAN HIPOTESIS}

\section{Investasi}

Investasi dapat diartikan sebagai komitmen atas sejumlah dana pada satu atau lebih jenis aset yang ditahan hingga masa yang akan dating Jones (2002:3). Secara umum investasi dibedakan menjadi dua, yaitu investasi pada aset-aset finansial (financial assets) dan investasi pada aset-aset riil (real assets). Investasi pada aset riil dapat berupa tanah, bangunan dan peralatan yang digunakan untuk memproduksi barang dan jasa. Sedangkan investasi pada aset finansial merupakan investasi dalam bentuk surat-surat berharga, seperti saham dan obligasi, yang pada dasarnya merupakan klaim atas suatu aset riil atau pendapatan yang dihasilkan dari aset tersebut (Bodie, et al., 2008:3).

\section{Indeks LQ 45}

Indeks LQ 45 terdiri dari 45 emiten yang dipilih berdasarkan pertimbangan likuiditas dan kapitalisasi pasar, dengan kriteria-kriteria yang telah ditentukan. Kriteria tersebut yaitu: telah tercatat di BEI minimal 3 bulan, aktivitas transaksi di pasar reguler berdasarkan nilai, volume dan frekuensi transaksi, jumlah hari perdagangan di pasar reguler dan kapitalisasi pasar pada periode waktu tertentu. Selain mempertimbangkan kriteria likuiditas dan kapitalisasi pasar, akan dilihat juga keadaan keuangan dan prospek pertumbuhan perusahaan tersebut. Evaluasi atas pergerakan urutan saham-saham dilakukan setiap 3 bulan sekali. Sedangkan penggantian saham akan dilakukan setiap enam bulan sekali, yaitu pada awal bulan Februari dan Agustus.

\section{Efisiensi Pasar Modal}

Jones (2002:316) menyatakan, "Information is the key to the determination of stock price and therefore is the central issue of the efficient markets concept". Sehingga dapat dikatakan efisiensi pasar merupakan hubungan antara harga sekuritas dengan informasi. Pasar modal yang efisien didefinisikan sebagai pasar yang harga sekuritassekuritasnya telah mencerminkan semua informasi yang relevan (Husnan, 1994:260). Pasar modal bereaksi terhadap suatu informasi baru untuk mencapai harga keseimbangan yang baru. Semakin cepat informasi baru tercermin pada harga sekuritas, semakin efisien pasar modal tersebut. Investor akan kesulitan untuk mendapatkan keuntungan abnormal (abnormal return) pada pasar modal yang efisien. Efisiensi pasar modal dapat dibedakan menjadi tiga berdasarkan ketersediaan informasi, yaitu efisiensi pasar bentuk lemah, 
efisiensi pasar bentuk setengah kuat dan efisiensi pasar bentuk kuat.

\section{Signaling Theory}

Signaling theory menyatakan bahwa pihak pengirim (pemilik informasi) berusaha memberikan potongan informasi relevan yang dapat dimanfaatkan oleh pihak penerima. Pihak penerima kemudian akan menyesuaikan perilakunya sesuai dengan pemahamannya terhadap sinyal tersebut (Oktaviana dan Wahyuni, 2011). Kappou et al. (2008) menyatakan, ketika suatu saham masuk atau keluar dari indeks, potongan informasi penting diungkapkan kepada publik. Cheung dan Roca (2013) menyatakan bahwa peristiwa ini diintrepertasikan oleh investor sebagai signal mengenai nilai masa depan sekuritas karena informasi superior yang dimiliki komite penilaian yang diungkapkan melalui event tersebut.

\section{Selection Criteria Hypothesis}

Selection criteria hypothesis menekankan pada kriteria yang ditetapkan untuk suatu saham perusahaan dapat masuk atau keluar dari suatu indeks. Menurut Li et al. (2000), reaksi pasar yang terjadi ketika saham masuk atau keluar indeks merupakan hasil fundamental saham itu sendiri. Saham yang masuk ke dalam indeks memiliki performa historis yang baik sehingga mengakibatkan peningkatan nilai kapitalisasi pasar, sedangkan saham yang dihapuskan dari indeks memiliki performa yang buruk. Ketika suatu saham memenuhi kriteria indeks tertentu, hal ini merupakan tanda bahwa perusahaan tersebut memiliki kinerja yang memuaskan (Duque dan Madeira, 2005:7).

\section{Return Saham}

Return merupakan pengembalian yang didapat dari berinvestasi (Jordan et al., 2012:2). Return saham atau pendapatan saham terdiri dari actual return, expected return dan abnormal return. Actual return atau pendapatan aktual merupakan return yang bersifat ex post atau return yang telah diperoleh (Jones, 2002:130). Expected return atau pendapatan yang diharapkan merupakan pendapatan yang diestimasi dari suatu aset yang investor harapkan akan dperoleh selama periode waktu mendatang (Jones, 2002:135). Expected return dapat dihitung menggunakan model mean-adjusted model, market model dan market adjusted model. Penelitian ini menggunakan market model untuk menghitung expected return. Market model adalah model yang menggabungkan pendapatan saham dengan pendapatan pasar untuk menghitung expected return. Sedangkan return tidak normal atau abnormal return adalah selisih antara return yang sesungguhnya terjadi 
dengan return ekspektasi (Jogiyanto, 2010:579).

\section{Volume Perdagangan Saham}

Volume perdagangan merupakan salah satu indikator yang dapat digunakan untuk melihat reaksi pasar terhadap informasi yang dipublikasikan selain abnormal return. Menurut Husnan (1994:30) volume transaksi saham menunjukkan jumlah saham emiten yang ditransaksikan dalam tingkat harga yang disepakati oleh pihak penjual dan pembeli selama periode transaksi. Kesempatan bertransaksi muncul karena pembeli dan penjual memiliki tingkat permintaan dan penawaran yang berbeda. Perbedaan yang timbul dipengaruhi oleh harapan investor mengenai prospek perusahaan dimasa yang akan datang yang berasal dari suatu informasi.

\section{Pengertian Event Study}

Bodie et al. (2008:381) menyatakan bahwa event study merupakan model teknik empiris keuangan yang digunakan peneliti untuk menilai dampak dari sebuah peristiwa tertentu terhadap harga saham perusahaan. Event study dapat digunakan untuk menguji kandungan informasi (information content) dari suatu pengumuman. Jika pengumuman mengandung informasi maka pasar diharapkan akan bereaksi ketika pengumuman tersebut diterima pasar. Reaksi ini dapat dilihat dari pergerakan harga saham yang diukur dengan return sebagai nilai perubahan harga atau dengan menggunakan abnormal return. Menurut McWilliam dan Siegel (1997) dalam Jogiyanto (2010:12), Studi peristiwa didasarkan pada tiga asumsi dasar, yaitu efisiensi pasar (market efficiency), peristiwaperistiwa tidak diantisipasi sebelumnya (unanticipated events) dan asumsi terakhir yaitu, tidak ada efek-efek pengganggu (no confounding effects).

\section{Reaksi Pasar Terhadap Saham yang Masuk dan Keluar Indeks LQ 45.}

Informasi dibutuhkan oleh investor untuk menentukan keputusan jual beli. Informasi dapat berasal dari dalam perusahaan maupun dari luar perusahaan. Pengumuman masuk indeks LQ 45 dapat menjadi informasi yang positif bagi investor. Hal ini dapat dikarenakan komite penilaian indeks memberikan sinyal positif tentang performa perusahaan yang sahamnya masuk ke dalam indeks LQ 45. Selain itu investor menganggap saham yang masuk ke dalam indeks mengungguli saham-saham yang lainnya karena lolos seleksi kriteria indeks LQ 45 yang juga melihat keadaan keuangan dan prospek pertumbuhan perusahaan sehingga menimbulkan persepsi positif bagi investor. 
Sebaliknya, pengumuman saham keluar indeks LQ 45 dapat menjadi informasi yang negatif bagi investor. Hal ini dapat dikarenakan komite penilaian indeks memberikan sinyal negatif tentang performa perusahaan yang sahamnya keluar dari indeks LQ 45. Selain itu investor menganggap saham yang masuk ke dalam indeks kalah performa dengan saham-saham yang lainnya karena tidak lolos seleksi kriteria indeks LQ 45 yang juga melihat keadaan keuangan dan prospek pertumbuhan perusahaan sehingga menimbulkan persepsi negatif bagi investor.

\section{Hipotesis}

1. Terdapat reaksi pasar yang ditunjukkan oleh average abnormal return, cumulative average abnormal return dan average volume ratio atas saham yang masuk dalam indeks LQ 45 di sekitar tanggal pengumuman.

2. Terdapat reaksi pasar yang ditunjukkan oleh average abnormal return, cumulative average abnormal return dan average volume ratio atas saham yang keluar dari indeks LQ 45 di sekitar tanggal pengumuman.

3. Terdapat perbedaan reaksi pasar atas saham yang masuk dan keluar indeks LQ 45 di sekitar tanggal pengumuman.

\section{METODE}

\section{Metode Seleksi dan Pengumpulan Data}

Penelitian ini menggunakan data sekunder yang diperoleh dari website Bursa Efek Indonesia (www.idx.co.id), KSEI (www.ksei.co.id) dan Yahoo Finance (www.finance.yahoo.com). Sampel penelitian ini terdiri atas 47 saham yang masuk indeks LQ 45 dan 43 saham yang keluar indeks LQ 45 yang dipilih berdasarkan kriteria sebagai berikut: (1) saham perusahaan yang masuk atau keluar dari indeks LQ 45, (2) saham perusahaan tersebut selalu ditransaksikan selama periode uji sehingga dapat diketahui harga saham dan volume perdagangan, (3) perusahaan tidak melakukan pengumuman lainnya seperti stock split, merger, akuisisi, pembagian dividen atau lainnya selama periode uji.

\section{Pengukuran dan Definisi operasional Variabel}

Untuk memberikan gambaran yang lebih jelas mengenai variabel yang digunakan dalam penelitian ini, masing-masing variabel dapat didefinisikan sebagai berikut:

1. Average abnormal return (AAR) merupakan rata-rata dari abnormal return (selisih antara return actual dengan expected return) pada hari ke-t yang diperoleh melalui rumus : 
$A A R_{t}=\frac{1}{N} \sum_{i=1}^{t} A R_{i t}$

$\mathrm{AAR}_{\mathrm{t}}=$ average abnormal return pada periode $\mathrm{t}$

$\mathrm{AR}_{\mathrm{it}}=$ abnormal return saham i pada periode $\mathrm{t}$, dengan rumus:

$A R_{i t}=R_{i t}-\mathrm{E}\left(\mathrm{R}_{\mathrm{it}}\right)$

$R_{i t} \quad=$ actual return saham $i$ pada hari periode $t$

$E\left(R_{i t}\right)=$ expected return saham $i$ pada periode $t$ yang dihitung menggunakan market model dengan periode estimasi 30 hari dan periode uji 11 hari.

$\mathrm{N} \quad=$ jumlah saham

2. Cumulative average abnormal return (CAAR) merupakan akumulasi harian rata-rata pendapatan abnormal mulai dari hari pertama sampai dengan hari-hari berikutnya, yang diperoleh melalui rumus :

$\mathrm{CAAR}_{\mathrm{t}}=\sum_{\mathrm{i}=1}^{\mathrm{t}} \mathrm{AAR}_{\mathrm{it}}$

$\mathrm{CAAR}_{\mathrm{t}}=$ cumulative average abnormal return saham $\mathrm{i}$ pada periode $\mathrm{t}$

$\mathrm{AAR}_{\text {it }}=$ average abnormal return untuk saham i pada periode $\mathrm{t}$

3. Average volume ratio (AVR) merupakan rata-rata dari volume ratio pada hari ke-t. Volume ratio mengukur volume saham relatif terhadap volume pasar untuk mendeteksi volume perdagangan abnormal selama periode uji (Bildik dan Gülay, 2008.). Jika tidak terdapat abnormal volume, maka volume ratio akan bernilai 1. AVR diperoleh melalui rumus :

$\mathrm{AVR}_{\mathrm{t}}=\frac{1}{\mathrm{~N}} \sum_{\mathrm{i}=1}^{\mathrm{N}} \mathrm{VR}_{\mathrm{it}}$

$\mathrm{AVR}_{\mathrm{t}}=$ average volume ratio

$\mathrm{VR}_{\mathrm{it}}=$ volume ratio, dihitung mengggunakan rumus:

$\mathrm{VR}_{\mathrm{it}}=\frac{\mathrm{V}_{\mathrm{it}}}{\mathrm{V}_{\mathrm{mt}}} \cdot \frac{\mathrm{V}_{\mathrm{m}}}{\mathrm{V}_{\mathrm{i}}}$

$\mathrm{V}_{\text {it }} \quad=$ volume perdagangan saham i pada periode uji $\mathrm{t}$

$\mathrm{V}_{\mathrm{i}} \quad=$ rata-rata volume perdagangan saham i selama periode estimasi

$\mathrm{V}_{\mathrm{mt}}=$ volume perdagangan pasar pada periode uji $\mathrm{t}$

$\mathrm{V}_{\mathrm{m}}=$ rata-rata volume perdagangan pasar selama periode estimasi

$\mathrm{N} \quad=$ jumlah sampel

\section{Metode Analisis Data}

Pendekatan yang digunakan dalam penelitian ini adalah pendekatan kuantitatif yang menitikberatkan pada pengujian hipotesis dan menghasilkan kesimpulan yang dapat 
digeneralisasi. Data yang digunakan terukur dan diolah menggunakan alat uji statistik. Metode analisis yang digunakan dalam penelitian ini adalah event study yang digunakan untuk menguji kandungan informasi (information content) dari suatu pengumuman.

\section{HASIL DAN PEMBAHASAN \\ Reaksi Pasar Atas Saham yang Masuk Indeks LQ 45}

Sesuai dengan konsep efisiensi pasar secara informasi, pasar akan bereaksi jika pengumuman masuk dan keluar saham indeks LQ 45 mengandung informasi yang berarti bagi investor. Hasil analisis pengujian sampel saham perusahaan yang masuk indeks LQ 45 menunjukkan tidak terdapat average abnormal return dan cumulative average abnormal return yang signifikan sebelum pengumuman saham masuk indeks LQ 45. Average abnormal return positif signifikan terjadi pada saat pengumuman saham masuk indeks LQ 45. Hasil signifikan juga ditemukan pada average volume ratio pada saat pengumuman masuk indeks LQ 45.

\section{Tabel 1}

Hasil Pengujian Signifikansi Average Abnormal Return, Cumulative Average Abnormal Return dan Average Volume Ratio Sampel Perusahaan yang Masuk Indeks LQ 45

\begin{tabular}{ccccccc}
\hline Hari & AAR & Sig. & CAAR & Sig. & AVR & Sig. \\
\hline-5 & 0,0003 & 0,931 & 0,0003 & 0,931 & 0,91 & $0,000^{*}$ \\
\hline-4 & $-0,0012$ & 0,760 & $-0,0009$ & 0,869 & 0,97 & $0,000^{*}$ \\
\hline-3 & 0,0030 & 0,350 & 0,0022 & 0,698 & 1,08 & $0,000^{*}$ \\
\hline-2 & $-0,0049$ & 0,055 & $-0,0028$ & 0,665 & 1,22 & $0,000^{*}$ \\
\hline-1 & $-0,0008$ & 0,844 & $-0,0036$ & 0,614 & 1,20 & $0,000^{*}$ \\
\hline 0 & 0,0066 & $0,034^{*}$ & 0,0031 & 0,672 & 1,21 & $0,000^{*}$ \\
\hline 1 & $-0,0040$ & 0,272 & $-0,0009$ & 0,910 & 1,02 & $0,000^{*}$ \\
\hline 2 & 0,0081 & 0,110 & 0,0071 & 0,456 & 0,93 & $0,000^{*}$ \\
\hline 3 & 0,0085 & 0,073 & 0,0156 & 0,124 & 1,41 & $0,000^{*}$ \\
\hline 4 & 0,0083 & 0,180 & 0,0238 & 0,085 & 1,29 & $0,000^{*}$ \\
\hline 5 & 0,0028 & 0,399 & 0,0267 & 0,053 & 1,02 & $0,000^{*}$
\end{tabular}

* Signifikan pada tingkat 5\%

Hasil ini sejalan dengan Liu (2000), yang menyatakan bahwa pasar tidak mengantisipasi saham mana yang akan masuk dalam suatu indeks. Saham yang terdaftar dalam indeks LQ 45 hanya sekitar 9\% dari keseluruhan saham yang tercatat di Bursa Efek Indonesia yang berjumlah 492 emiten, sehingga sulit bagi investor menentukan saham mana yang akan masuk dalam indeks LQ 45 yang menyebabkan tidak ditemukan reaksi pasar signifikan sebelum pengumuman masuk indeks LQ 45. Reaksi pasar signifikan terjadi pada saat pengumuman indeks LQ 45, terdapat average abnormal return pada saat pengumuman yang diiringi kenaikan average volume ratio. Hal ini mengindikasikan meningkatnya aktivitas perdagangan yang mendorong kenaikan harga saham. Perubahan 
harga saham mencerminkan perubahan persepsi atau penilaian investor terhadap suatu saham. Investor memiliki persepsi yang baik atas saham yang masuk dalam indeks LQ 45 karena saham yang masuk indeks LQ 45 telah lolos seleksi kriteria indeks LQ 45 dan termasuk dalam kelompok saham yang memiliki likuiditas dan kapitalisasi pasar tinggi. Nilai CAAR yang didominasi nilai positif sepanjang periode uji menunjukkan investor yang berinvestasi pada saham yang masuk indeks LQ selama periode uji akan mendapatkan keuntungan. Hasil penelitian yang menunjukkan terdapat abnormal return dan abnormal volume positif atas saham yang masuk indeks LQ 45 sejalan dengan Liu (2000), Duque dan Madeira (2005), Qiu dan Pinfold (2008), Harzdil (2009), serta Rahman dan Rajib (2013).

\section{Reaksi Pasar Atas Saham yang Keluar Indeks LQ 45}

Hasil analisis pengujian sampel perusahaan yang keluar indeks LQ 45 menunjukkan terdapat average abnormal return negatif signifikan pada hari kelima dan average abnormal return positif signifikan hari pada kedua sebelum pengumuman keluar indeks LQ 45 dan terdapat cumulative average abnormal return signifikan pada hari kelima sebelum pengumuman keluar indeks LQ 45. Average abnormal return signifikan diatas satu juga ditemukan pada hari kelima dan hari kedua sebelum pengumuman keluar indeks LQ 45.

\section{Tabel 2}

Hasil Pengujian Signifikansi Average Abnormal Return, Cumulative Average Abnormal Return dan Average Volume Ratio Sampel Perusahaan yang Keluar Indeks LQ 45

\begin{tabular}{ccccccc}
\hline Hari & AAR & Sig. & CAAR & Sig. & AVR & Sig. \\
\hline-5 & $-0,0067$ & $0,029 *$ & $-0,0067$ & $0,029 *$ & 1,10 & $0,000^{*}$ \\
\hline-4 & $-0,0024$ & 0,623 & $-0,0091$ & 0,115 & 1,29 & $0,00 *^{*}$ \\
\hline-3 & 0,0021 & 0,631 & $-0,0070$ & 0,161 & 1,14 & $0,000^{*}$ \\
\hline-2 & 0,0099 & $0,006^{*}$ & 0,0030 & 0,670 & 1,43 & $0,00 *^{*}$ \\
\hline-1 & $-0,0045$ & 0,289 & $-0,0015$ & 0,866 & 1,39 & $0,000^{*}$ \\
\hline 0 & 0,0004 & 0,932 & $-0,0011$ & 0,927 & 1,07 & $0,003 *$ \\
\hline 1 & 0,0045 & 0,487 & 0,0034 & 0,833 & 1,45 & $0,011 *$ \\
\hline 2 & $-0,0023$ & 0,494 & 0,0011 & 0,946 & 0,95 & $0,000 *$ \\
\hline 3 & $-0,0063$ & 0,080 & $-0,0051$ & 0,744 & 0,94 & $0,000 *$ \\
\hline 4 & $-0,0016$ & 0,743 & $-0,0068$ & 0,699 & 1,55 & $0,002^{*}$ \\
\hline 5 & 0,0018 & 0,819 & $-0,0050$ & 0,819 & 1,69 & $0,000 *$
\end{tabular}

* Signifikan pada tingkat 5\%

Hasil pengujian menunjukkan bahwa pasar bereaksi sebelum ada pengumuman saham yang keluar dari indeks LQ 45. Hasil ini sejalan dengan Liu (2000) yang menyatakan terdapat antisipasi dari pasar atas saham yang keluar indeks LQ 45. Sahamsaham yang terdapat dalam indeks LQ 45 dapat dikategorikan sebagai saham blue-chip 
sehingga mendapatkan perhatian lebih dari investor. Pada dasarnya investor adalah risk averse yang peka terhadap kerugian. Ketika suatu saham dari indeks LQ 45 mengalami penurunan dalam likuiditas dan performa saham tentu saja hal ini telah diantisipasi oleh investor sehingga investor telah bereaksi sebelum ada pengumuman saham mana yang keluar dari indeks LQ 45. Persepsi negatif investor atas saham yang keluar indeks LQ 45 tercermin pada average abnormal return yang negatif signifikan yang sejalan dengan adanya abnormal volume signifikan pada hari kelima sebelum pengumuman. Hal ini mengindikasikan reaksi investor menjual saham yang mendorong penurunan harga saham. Abnormal return positif pada hari kedua sebelum pengumuman sejalan dengan abnormal volume pada hari yang sama yang mengindikasikan adanya aktivitas beli investor yang mendorong harga saham.

Cumulative average abnormal return yang signifikan pada hari kelima sebelum pengumuman keluar indeks LQ 45 sejalan dengan average abnormal return yang juga signifikan pada hari tersebut menandakan bahwa sebaiknya investor menjual saham yang keluar indeks LQ 45. Hasil penelitian yang menunjukkan pasar bereaksi negatif atas saham yang keluar indeks sejalan dengan Liu (2000) dan Duque dan Madeira (2005),

\section{Perbedaan Reaksi Pasar Atas Saham yang Masuk dan Keluar Indeks LQ 45}

Hasil analisis average abnormal return perusahaan yang masuk dan keluar indeks LQ 45 dengan menggunakan uji beda independent sample t-test menunjukkan terdapat perbedaan average abnormal return yang signifikan antara saham perusahaan yang masuk dengan saham perusahaan yang keluar indeks LQ 45 pada hari kedua sebelum dan hari ketiga setelah pengumuman masuk dan keluar indeks LQ 45. AAR saham yang masuk indeks LQ 45 bernilai negatif sebesar -0,0049 sedangkan nilai AAR saham yang keluar indeks LQ 45 bernilai positif sebesar 0,0114. Hal ini dikarenakan terdapat reaksi pasar yang ditunjukkan dengan average abnormal return signifikan atas saham yang keluar dari indeks LQ 45 pada hari kedua sebelum pengumuman.

\section{Tabel 3}

Hasil Uji Beda Average Abnormal Return Sampel Saham yang Masuk dan Keluar Indeks LQ 45

\begin{tabular}{ccccc}
\hline Hari & $\begin{array}{c}\text { AAR Saham } \\
\text { Masuk Indeks } \\
\text { LQ 45 }\end{array}$ & $\begin{array}{c}\text { AAR Saham } \\
\text { Keluar Indeks } \\
\text { LQ 45 }\end{array}$ & Levene Test Sig & Sig \\
\hline-5 & 0,0003 & $-0,0067$ & 0,341 & 0,135 \\
\hline-4 & $-0,0012$ & $-0,0024$ & 0,481 & 0,838 \\
\hline-3 & 0,0030 & 0,0021 & 0,293 & 0,870 \\
\hline-2 & $-0,0049$ & 0,0099 & 0,272 & $0,001^{*}$
\end{tabular}




\begin{tabular}{ccccc}
\hline Hari & $\begin{array}{c}\text { AAR Saham } \\
\text { Masuk Indeks } \\
\text { LQ 45 }\end{array}$ & $\begin{array}{c}\text { AAR Saham } \\
\text { Keluar Indeks } \\
\text { LQ 45 }\end{array}$ & Levene Test Sig & Sig \\
\hline-1 & $-0,0008$ & $-0,0045$ & 0,799 & 0,530 \\
\hline 0 & 0,0066 & 0,0004 & 0,681 & 0,292 \\
\hline 1 & $-0,0040$ & 0,0045 & 0,469 & 0,241 \\
\hline 2 & 0,0081 & $-0,0023$ & 0,215 & 0,091 \\
\hline 3 & 0,0085 & $-0,0063$ & 0,140 & $0,014^{*}$ \\
\hline 4 & 0,0083 & $-0,0016$ & 0,345 & 0,215 \\
\hline 5 & 0,0028 & 0,0018 & 0,089 &
\end{tabular}

Setelah pengumuman masuk dan keluar indeks LQ 45 terdapat perbedaan average abnormal return yang signifikan pada hari ketiga. Nilai AAR saham yang masuk indeks LQ 45 bernilai positif sebesar 0,0085 sedangkan nilai AAR saham yang keluar indeks LQ 45 bernilai negatif sebesar $-0,0063$. Hal ini dikarenakan pasar masih bereaksi atas saham yang masuk indeks LQ 45 Sementara untuk cumulative average abnormal return dan average volume ratio saham yang masuk dan keluar indeks LQ 45 tidak terdapat perbedaan yang signifikan.

Tabel 4

Hasil Uji Beda Cumulative Average Abnormal Return Sampel Saham yang Masuk dan Keluar Indeks LQ 45

\begin{tabular}{ccccc}
\hline Hari & $\begin{array}{c}\text { CAAR Saham } \\
\text { Masuk Indeks } \\
\text { LQ 45 }\end{array}$ & $\begin{array}{c}\text { CAAR Saham } \\
\text { Keluar Indeks } \\
\text { LQ 45 }\end{array}$ & Levene Test Sig & Sig \\
\hline-5 & 0,0003 & $-0,0067$ & 0,341 & 0,135 \\
\hline-4 & $-0,0009$ & $-0,0091$ & 0,486 & 0,288 \\
\hline-3 & 0,0022 & $-0,0070$ & 0,117 & 0,224 \\
\hline-2 & $-0,0028$ & 0,0030 & 0,896 & 0,542 \\
\hline-1 & $-0,0036$ & $-0,0015$ & 0,302 & 0,859 \\
\hline 0 & 0,0031 & $-0,0011$ & 0,331 & 0,762 \\
\hline 1 & $-0,0009$ & 0,0034 & 0,206 & 0,805 \\
\hline 2 & 0,0071 & 0,0011 & 0,339 & 0,753 \\
\hline 3 & 0,0156 & $-0,0051$ & 0,469 & 0,258 \\
\hline 4 & 0,0238 & $-0,0068$ & 0,721 & 0,164 \\
\hline 5 & 0,0267 & $-0,0050$ & 0,166 & 0,210
\end{tabular}

Tabel 5

Hasil Uji Beda Average Volume Ratio Sampel Saham yang Masuk dan Keluar Indeks LQ 45

\begin{tabular}{ccccc}
\hline Hari & $\begin{array}{c}\text { AVR Saham } \\
\text { Masuk Indeks } \\
\text { LQ 45 }\end{array}$ & $\begin{array}{c}\text { AVR Saham } \\
\text { Keluar Indeks } \\
\text { LQ 45 }\end{array}$ & Levene Test Sig & Sig \\
\hline-5 & 0,91 & 1,10 & 0,060 & 0,471 \\
\hline-4 & 0,97 & 1,29 & 0,042 & 0,358 \\
\hline-3 & 1,08 & 1,14 & 0,181 & 0,829 \\
\hline-2 & 1,22 & 1,43 & 0,990 & 0,561 \\
\hline-1 & 1,20 & 1,39 & 0,076 & 0,584 \\
\hline 0 & 1,21 & 1,07 & 0,763 & 0,694
\end{tabular}




\begin{tabular}{ccccc}
\hline Hari & $\begin{array}{c}\text { AVR Saham } \\
\text { Masuk Indeks } \\
\text { LQ 45 }\end{array}$ & $\begin{array}{c}\text { AVR Saham } \\
\text { Keluar Indeks } \\
\text { LQ 45 }\end{array}$ & Levene Test Sig & Sig \\
\hline 1 & 1,02 & 1,45 & 0,077 & 0,417 \\
\hline 2 & 0,93 & 0,95 & 0,144 & 0,919 \\
\hline 3 & 1,41 & 0,94 & 0,182 & 0,093 \\
\hline 4 & 1,29 & 1,55 & 0,241 & 0,600 \\
\hline 5 & 1,02 & 1,69 & 0,001 & 0,057
\end{tabular}

\section{SIMPULAN}

Berdasarkan analisis dan pembahasan yang telah dikemukakan sebelumnya, maka dapat ditarik kesimpulan sebagai berikut:

1. Terdapat average abnormal return positif signifikan yang sejalan dengan average volume ratio diatas angka satu yang signifikan pada saat pengumuman masuk indeks LQ 45. Hal ini mengindikasikan meningkatnya aktivitas perdagangan yang mendorong kenaikan harga saham. Hal ini mengindikasikan investor memiliki persepsi yang baik atas saham yang masuk dalam indeks LQ 45 karena saham yang masuk indeks LQ 45 telah lolos seleksi kriteria indeks LQ 45 dan termasuk dalam kelompok saham yang memiliki likuiditas dan kapitalisasi pasar tinggi.

2. Hasil pengujian atas saham yang keluar indeks LQ 45 menunjukkan bahwa pasar bereaksi sebelum ada pengumuman saham yang keluar dari indeks LQ 45. Hal ini ditunjukkan dengan average abnormal return negatif signifikan pada hari kelima dan average abnormal return positif signifikan hari pada kedua sebelum pengumuman keluar indeks LQ 45 dan terdapat cumulative average abnormal return signifikan pada hari kelima sebelum pengumuman keluar indeks LQ 45. Average abnormal return signifikan diatas angka satu juga ditemukan pada hari kelima dan hari kedua sebelum pengumuman keluar indeks LQ 45. Hal ini dikarenakan investor telah mengamati performa saham dalam indeks LQ 45 dan telah mengantisipasi saham yang mengalami penurunan likuiditas dan performanya sebelum ada pengumuman saham keluar indeks LQ 45.

3. Hasil uji beda average abnormal return perusahaan yang masuk dan keluar indeks LQ 45 menunjukkan terdapat perbedaan average abnormal return yang signifikan antara saham perusahaan yang masuk dengan saham perusahaan yang keluar indeks LQ 45 pada hari kedua sebelum dan hari ketiga setelah pengumuman masuk dan keluar indeks LQ 45. Hal ini dikarenakan pasar bereaksi sebelum pengumuman atas saham yang keluar indeks LQ 45 dan saham yang keluar indeks LQ 45 bereaksi saat 
dan sesudah pengumuman. Sementara untuk cumulative average abnormal return dan average volume ratio saham yang masuk dan keluar indeks LQ 45 tidak terdapat perbedaan yang signifikan.

\section{DAFTAR PUSTAKA}

Bildik, R., dan Gülay, G. 2008. The Effect of Changes in Index Composition on Stock Prices and Volume: Evidence From the Istambul Stock Exchange. International Review of Financial Analysis (17). Hlm 178-197.

Bodie, Z., Kane, A. dan Marcus, A. J. 2008. Investasi. Jakarta: Salemba Empat.

Brooks, C., Kappou, A., Stevenson, S., dan Ward, C. 2013. The Performance Effects of Composition Changes on Sector Specific Stock Indices: The Case of European Listed Real Estate. International Review of Financial Analysis (29). Hlm 132142.

Brown, S.J. dan J.B. Warner, 1985. Using Daily Stock Returns: The case of Event Studies. Journal of Financial economics (14). Hlm 3-31.

Bursa Efek Indonesia. 2010. Buku Panduan Indeks Harga Saham Bursa Efek Indonesia. Cheung, A. dan Roca, E. 2013. The Effect on Price, Liquidity and Risk When Stocks Are Added To and Deleted From A Sustainability Index: Evidence From The Asia Pacific Context. Journal of Asian Economics (24). Hlm 51-65.

Darmadji, T. dan Fakhruddin, H.M. 2001. Pasar Modal di Indonesia: Pendekatan Tanya Jawab. Edisi Pertama. Jakarta: Salemba Empat.

Duque, J. dan Madeira, G. 2004. Effects Associated with Index Composition Changes: Evidence From Euronext Lisbon Stock Exchange (Online), (http://www.fep.up.pt/investigacao/cempre/actividades/sem_fin/sem_fin_01/PAP ERS_PDF/paper_sem_fin_31jan05.pdf., diakses 27 Maret 2014).

Halim, A. 2005. Analisis Investasi. Edisi Kedua. Jakarta: Salemba Empat.

Hegde, S.P. dan McDermott , J.B. 2003. The Liquidity Effects of Revisions to The S\&P 500 Index: An Empirical Analysis. Journal of Financial Markets (6). Hlm 413459.

Hrazdil, K. 2009. The Price, Liquidity and Information Asymmetry Changes Associated with New S\&P 500 Additions. Managerial Finance (35). Hlm 579-605.

Husnan, S. 1994. Dasar-dasar Teori Portofolio dan Analisis Sekuritas. Edisi Kedua. Yogyakarta: UPP AMP YKPN.

Jogiyanto, H.M. 2010. Teori Portofolio dan Analisis investasi. Cetakan Pertama. Yogyakarta: BPFE.

Jones, C.P. 2002. Investments: Analysis and Management. Eight Edition. USA: John Wiley \& Sons, Inc.

Jordan, B.J., Miller, T.W. dan Dolvin, S.D. 2012. Fundamentals of Investments: Valuation and Management. Sixth Edition. New York: McGraw-Hill.

Kappou, K., Brooks, C., dan Ward, C.W.R. 2008. A Re-Examination of The Index Effect: Gambling on Additions To and Deletions From The S\&P 500's 'Gold Seal'. 
Research in International Business and Finance (22). Hlm 325-350.

Effects of Changes to the Composition of New Zealand Share Indices, (Online), (http://papers.ssrn.com/sol3/papers.cfm?abstract_id=242649, diakses 27 Maret 2014).

Liu, S. 2000. Changes in The Nikkei 500: New Evidence for Downward Sloping Demand Curves for Stocks, http://papers.ssrn.com/sol3/papers. cfm?abstract_id=258300, diakses tanggal 20 November 2013).

McWilliams, A. Dan siegel, D. 1997. Event Studies in Management Research: Theoritical and Empirical Issues. Academy of Management Journal, Vol 40 (3). Hlm 626-657.

Oktaviana, U.K. dan Wahyuni, N. 2011. Pengaruh Perubahaan Komposisi Jakarta Islamic Index Terhadap Return Saham. Jurnal eL-QUDWAH. Hlm 1-21.

Ong, E. 2011. Technical Analysis for Mega Profit. Cetakan Ketujuh. Jakarta: PT. Gramedia Pustaka Utama.

Qiu, M. dan Pinfold, J. 2008. Price And Trading Volume Reactions To Index Constitution Changes. Journal of Managerial Finance, Vol 34 (1). Hlm 53-69.

Rahman, A. dan Rajib, P. 2013. Associated Effects of Index Composition Changes: An Evidence from The S\&P CNX Nifty 50 Index. Journal of Managerial Finance, Vol 40 (4). Hlm 376-394.

Reilly, F. dan Brown, K.C. 2003. Investment Analysis and Portfolio Management. Seventh Edition. USA: Thomson South-Western Inc.

Samsul, M. 2006. Pasar Modal dan Manajemen Portofolio. Jakarta: Penerbit Erlangga.

Tandelilin, E. 2011. Analisis Investasi dan Manajemen Porotfolio. Edisi Pertama. Yogyakarta : BPFE.

http://finance.yahoo.com/

http://www.idx.co.id/ 